Scientific journal

PHYSICAL AND MATHEMATICAL EDUCATION

Has been issued since 2013.

Науковий журнал

ФІЗИКО-МАТЕМАТИЧНА ОСВІТА

Видається з 2013.
ISSN 2413-158X (online)

ISSN 2413-1571 (print)

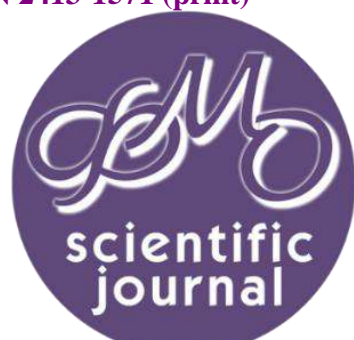

Атамась А.І., Сліпухіна І.А., Чернецький І.С., Шиховцев Ю.С. Суперконденсатор як дидактичний засіб навчання учнів основам електроніки у середовищі NI Multisim. Фізико-математична освіта. 2020. Випуск 2(24). С. 7-12.

Atamas A., Slipukhina I., Chernetskyi I., Shykhovtsev Yu. Supercapacitor as a didactic means of teaching students fundamentals of electronics in the NI Multisim environment. Physical and Mathematical Education. 2020. Issue 2(24). P. 7-12.

DOI 10.31110/2413-1571-2020-024-2-001

UDC (004.42:004.415.2)+62+53-057.8+(373.51:378.047)(045)

Artem Atamas

National Center "Junior Academy of Sciences of Ukraine», Ukraine art.atamas@gmail.com

ORCID: 0000-0002-8709-3208

Iryna Slipukhina

National aviation university, Ukraine slipukhina2015@gmail.com ORCID: 0000-0002-9253-8021

Ihor Chernetskyi

National Center "Junior Academy of Sciences of Ukraine», Ukraine manlabkiev@gmail.com

ORCID: 0000-0001-9771-7830

Yurii Shykhovtsev

National Center "Junior Academy of Sciences of Ukraine", Ukraine yushykh@gmail.com

ORCID: 0000-0001-7000-7003

\title{
SUPERCAPACITOR AS A DIDACTIC MEANS OF TEACHING STUDENTS FUNDAMENTALS OF ELECTRONICS IN THE NI MULTISIM ENVIRONMENT
}

\section{ABSTRACT}

Problem formulation. Educational researches of technologically actual and perspective models of devices with the use of simulation environments have allocated a special didactic niche. The demand for NI Multisim as a propaedeutic tool for the formation of engineering skills requires a study of the organizational and methodological foundations of its integration into the modern educational environment.

Materials and methods. Theoretical (comparative analysis of scientific data, modeling of the methodical system of learning using simulation environments, etc.), empirical (mostly observational) methods, as well as computer modeling of the studied devices were used. Preliminary didactic approbation was carried out within the framework of the project "Summer Physical and Technical Schools" of the National Center "Junior Academy of Sciences of Ukraine".

Results. Features of the supercapacitor as a means of learning the basics of electronics using the STEM approach are systematized in the form of a structural and functional diagram. The educational method is based on the use of the equivalent circuit. The virtual study of serial supercapacitors consists of calculation of parameters and construction of an equivalent circuit in the NI Multisim environment, analysis of charging (discharging) characteristics, and their dependence on external (internal) factors. By the instrumentality of a real experiment, it is possible to determine the specific energy consumption of the supercapacitor also. The technique of using a printed model of the supercapacitor complements the experiment with the possibility to determine the specific capacity of the carbon material, the impact of the concentration of the electrolyte used on the characteristics of the device. 3D printing can be a part of an educational STEM project.

Conclusions. Techniques based on the creation of equivalent circuits with simulation environments provide the potential to design educational studies of properties and related processes of a real, serial device, as well as of one manufactured in the laboratory. The possibility of using passport data of serial products creates didactic opportunities for the transition from an algorithmic laboratory project to independent educational research, in particular, distance or mobile learning. Relevant techniques based on 3D printing, as well as pedagogical aspects of STEM-oriented learning of the basics of electronics, require further research.

KEY WORDS: supercapacitor, basics of electronics, equivalent circuit, NI Multisim, STEM, STEM-laboratory MANLab, 3D printing. 


\section{INTRODUCTION}

Formulation of the problem. Virtual laboratories, in particular, software tools for electronic circuits modeling, are an integral part of the educational environment for teaching physical and technical disciplines. Electronics Workbench and its successor NI Multisim are invariably popular in this context (Atamas, Chernetskyi \& Shapovalov, 2017). In teaching students the basics of electronics and electrical engineering, preference should now be given to the STEM-approach, capable of comprehensively forming "hard skills" and "soft skills". Note that the research of didactic features of the study of electromagnetism and the basics of electronics using simulation programs (NI Multisim 11.0), is one of the activities of the STEMlaboratory of the MANLab National Center "Junior Academy of Sciences of Ukraine". The approbated training methods in the form of technological maps or instructions with step-by-step procedures are regularly updated and put to free access on the online resource stemua.science ${ }^{1}$; they are also designed as a workbook (Atamas, Chernetskyi \& Shapovalov, 2017).

Techniques that combine the study of the parameters of virtual, and therefore idealized, and real electrical schemes have a special pedagogical effect in this context. However, despite the active use of these environments as a means of forming physical and technical knowledge and engineering skills, the didactic principles of their use for teaching school-age youth, especially in STEM-oriented methods, have been studied very little.

Literature Review. Literature sources analysis has shown that the Electronics Workbench and NI Multisim software are actively used in the teaching process, in formal and non-formal education. The use of virtual platforms for simulations of electronic/electric circuits creates a connection of lectures and practical application (Noga \& Palczynska, 2018), has a significant didactic effect in the teaching of engineering disciplines (Ptak, 2018), deepens understanding of the sources of differences between real and virtual circuit elements. Especially, if the laboratory projects are constructed in a such a way that they contain actual measurements of a real electric circuit and in a simulation model (Lyubomirov et al., 2019), increase the level of students' perception of theoretical and mathematical models and are effective for project-oriented learning (Srikanth et al., 2019). It should be noted that $\mathrm{NI}$ Multisim is also used to model processes in solid materials or biological systems, for example, for interactive predictive simulation of flows of layered, heterogeneous, anisotropic media in reservoirs (Chin \& Zhuang, 2020).

An important component of modeling electronic devices is the study of functional ratios between electrical quantities, as well as mathematical analysis of experimental data in the context of error calculation, for example, establishing the dependence of transistor gain on currents (Djalal \& HR, 2019) or comparing calculated theoretical values of resonant frequency and $Q$ factor with the results obtained on the simulation in the Multisim 11.0 environment (MANLab, 2018). Obviously, this process is accompanied by the analysis of tabular and graphical data and requires the involvement of appropriate software, such as Microsoft Excel.

It should be noted that in order to enhance cognitive activity and increase students' motivation, it is important to study the structure and characteristics of technologically promising devices: both those that are still in the research phase, such as memristor (Bodduna, 2019), and those that are the basis of modern technology, for example, photoelectric converter, photodiode, various electric machines and others.

One of such didactically attractive devices is a supercapacitor (SC), which occupies a separate niche of utilization in consumer electronics, various gadgets, electric vehicles, and other stationary and industrial frameworks (Inamuddin et al., 2020). As an element of an electrical circuit, a SC or ionizer is an electrochemical device that, by its characteristics, occupies an intermediate position between the capacitor and the chemical current source (Conway, 2009). Compared to conventional batteries, SCs have significantly higher charge/discharge currents and significant cyclic life (up to 1 million charge-discharge cycles), however, it has a lower specific energy consumption. Therefore, it is used as a stand-alone or additional (as a part of accumulators with electrochemical batteries) electrical energy storage, as well as a smoothing capacitor for rectifiers (Kebede \& Ezema, 2020). For example, SCs can be backup power supplies for motherboards, microprocessors, and storage devices, additional elements in renewable energy storage devices (significantly expanding the range of current loads on the drive and improving the operating conditions of electrochemical batteries). They are also indispensable for the needs of high charging and discharging currents, for example, in technical systems ${ }^{2}$ for starting engines, uninterruptible power supply, peak power equalization, braking electric vehicles, etc. (Yu, Chabot \& Zhang, 2017).

In terms of physical structure, a is a capacitor that consists of two double electrical layers connected in series through a liquid electrolyte with a certain resistance ${ }^{3}$ (Conway, 2009). The values of the nominal capacity of SCs available on the market of electronic devices are in the range from $0.047 \mathrm{~F}^{4}$ to $500 \mathrm{~F}^{5}$. Note that the key role in the operation of this device is played by electrodes, which are made of materials with a significant specific surface area. This is the cause of the large area of the double electrical layer, which explains the large electrical capacity of SCs. Such electrodes are usually made using porous materials such as activated carbon or foamed metal (Inamuddin et al., 2020). The current requirements for the design of modern devices based on SCs are best met by synthetic materials with predefined characteristics based on graphene, such as graphene oxide, fullerenes and carbon nanotubes of a wide range of sizes (Kebede \& Ezema, 2020).

To study electronic devices in simulation environments, an approach is used that is based on the use of an equivalent circuit of a real element, which should fully reproduce the functional and constructive properties of the real artifact (Johnson, 2013). Such electrical models can be considered both as a simple RLC circuit and as a complex electrical circuit with nonlinear

\footnotetext{
${ }^{1}$ The average number of online requests to stemua.science in $2019 / 20$ is more than 600 thousand people / month, and the average number of uniquevisitors - is more than 20 thousand people / month, mostly from Ukraine, USA, Germany, Estonia and others (according to SEO data Cloud flare)

${ }^{2}$ Supercapacitors.Explain that Stuff https://www.explainthatstuff.com/how-supercapacitors-work.html

${ }^{3}$ The transition from the use of an aqueous solution of $\mathrm{KOH}$ or $\mathrm{H}_{2} \mathrm{SO}_{4}$ to solutions of organic and inorganic salts in organic solvents as an electrolyte made it possible to increase the rated charging voltage of supercapacitors from 1 to $2.7 \mathrm{~V}$.

${ }^{4}$ https://www.rcscomponents.kiev.ua/product/scdk5r5473-c-superkondensator_123727.html

${ }^{5}$ https://www.rcscomponents.kiev.ua/product/500f-2-7v-35x60mm 119286.html
} 
parameters, as well as applied to various DC and AC simulations ${ }^{6}$. The use of equivalent circuits creates opportunities to identify and study the dependence of the properties of the device on those of its parameters that cannot be changed in a non-destructive way, for example, on the internal resistance. Thus, failure to take into account the own active resistance of the SC at the design stage of the device can lead to undesirable effects in real electrical circuits, for example, to voltage ripples in power supplies and changes of the frequency characteristics of circuits. In addition, these devices have a leakage current, or self-discharge current, due to peculiarities of its structure and imperfection of electrochemical processes.

The use of equivalent circuits is indispensable in the study of the characteristics of new synthesized structures for electronic devices, such as material for SC electrodes. In such a way, in particular, the potential intervals of capacitive and pseudocapacitive energy accumulation at the interface with the electrolyte for carbon supramolecular structures with a hierarchical architecture were identified (Grygorchak et al., 2019).

Given the above, it is obvious that full-scale experiments with real electronic devices, supplemented by the processes of design and analysis of equivalent substitution schemes have significant didactic potential, especially for the organization of STEMoriented learning. However, the analysis of literature data and scientific reports available on the Internet showed that the use of $\mathrm{NI}$ Multisim and similar software products in the context of propaedeutics of electronics and electrical substitution circuits as teaching methods have been insufficiently studied. The need to solve this problem outlined the purpose of the article: to create a modern STEM-oriented method of teaching the basics of electronics, which is based on the study of physical properties of a technologically relevant device (e.g., SC) and didactic combination of full-scale and virtual experiments and 3D modeling.

\section{METHODOLOGY AND METHODS}

The study is performed through using such theoretical methods as comparative analysis to compare approaches to the study of electronics, current data on the research topic, available on science metric resources Scopus, Web of Science, Resarch Gate, Google Academy, innovative pedagogical experience, modeling of methodological system of teaching based on the use of equivalent substitution schemes and simulation environments. Empirical methods used in the study were are, first of all, observational methods, conversations with teachers, mentors and students, chronometry, analysis of textual and oral reports of performed research projects. Computer modeling and theoretical analysis of physical and technical characteristics of the studied devices were also used.

The full-scale experiment technique design process and testing of the equivalent circuit for SCs was carried out on the basis of technical documentation, which is freely available for three models (EECF5R5U105 (Panasonic) 1F 5.5 V, SE-5R5-D105VYV (KAMCAP) 1F 5.5 V and ESHSR-0005C0-002R7 (NESSCAP) 5F, 2.7 V), training typesetting kit for electrical circuits, digital measuring system with voltage and current sensors, an adjustable power supply and a multimeter.

Didactic approbation of educational and research projects "Research of a SC and construction of its equivalent circuit" and "Manufacture and research of an electrochemical capacitor" was carried out in 2016 - 2019 within the project "Summer Physical and Technical Schools" with the participation of students of grades 8-11 in the educational activities of the National Center "Junior Academy of Sciences of Ukraine".

\section{RESULTS AND DISCUSSION}

The analysis of a SC as a means of teaching the basics of electronics using the STEM approach created the basis for systematization of the obtained data in the form of structural and functional diagram, which reflects the didactic features of manufacturing and research of this device in a laboratory layout cell, virtual research of SCs with an equivalent scheme and fullscale laboratory experiment with real artifacts (Fig. 1).

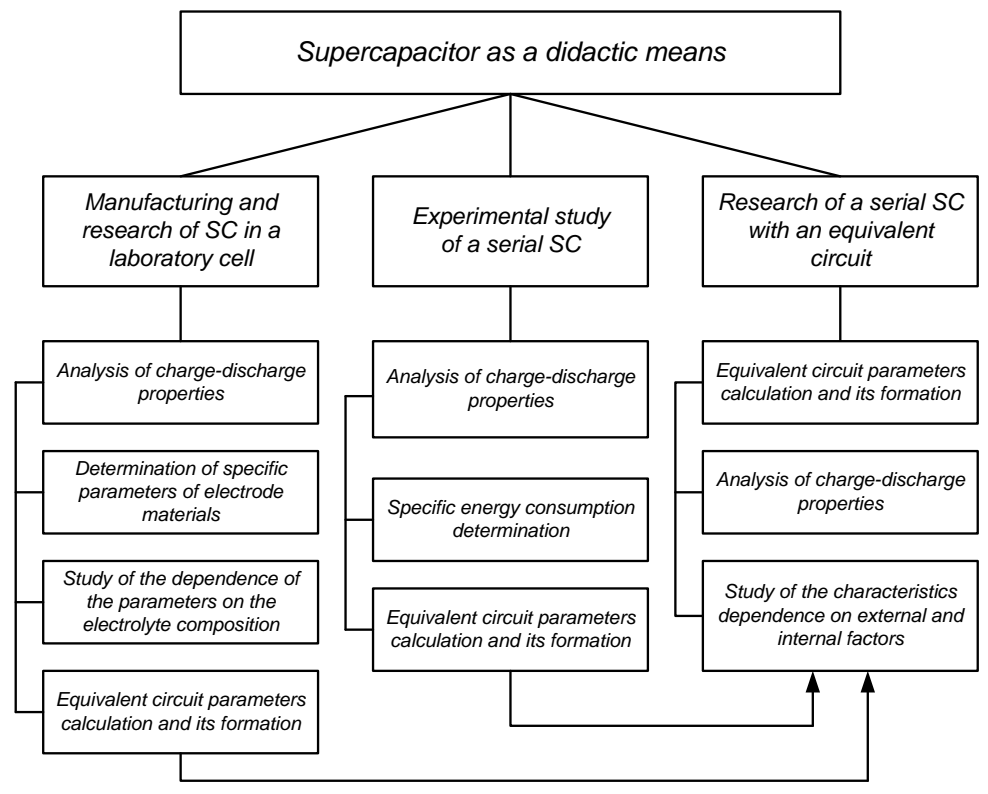

Fig. 1. Supercapacitor as a didactic means

\footnotetext{
${ }^{6}$ Equivalent Circuits and Simulation Models - Circuit Types. Passive Components Blog https://passive-components.eu/
} 
The virtual study of serial SCs consists of calculation of parameters and construction of an equivalent circuit in the NI Multisim environment, analysis of charging (discharge) characteristics and their dependence on external (internal) factors. In the field experiment additionally determine the specific energy consumption of the SC. The technique using a printed 3D model of the SC complements the experiment with the ability to determine the specific capacity of the carbon material, the effect of the concentration of the electrolyte used on the characteristics of the device.

Consider the procedure for the study of serial SC according to the equivalent scheme, the technological map of which is given in the section "Research projects" (MANLab, 2018). To achieve this goal, an equivalent circuit design, which reflects the capacities of each double electrical layer separately and thus demonstrates the features of the structure of the SC (Yu, Chabot \& Zhang, 2017, P. 67) is didactically justified. At the beginning of the study, students, using the means of digital measuring system, experimentally determine the total capacity, internal resistance and leakage resistance of the real SC $\mathrm{SC}^{7}$ The next stage of the study is to create a model of the SC and find out the changes in its charging (discharge) characteristics with a decrease (increase) in internal resistance. In this context, students are aware of the feasibility and need to create an equivalent circuit, for example, in the NI Multisim environment (Fig. 2).

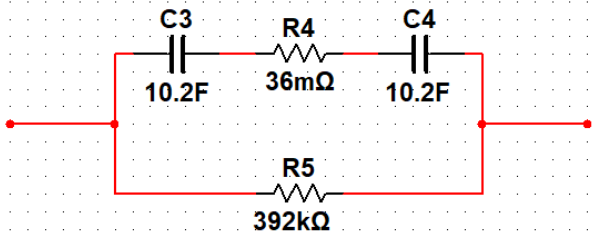

Fig. 2. Equivalent circuit of the SC in NI Multisim 11.0 environment

Practice has shown that the charging and discharging characteristics of the SC with the actual and modified resistances are measured "in parallel", using a two-channel oscilloscope and the corresponding equivalent circuits, located in one file. Later on, the investigated devices (SC1 with actual internal resistance, $S C 2$ - with modified) are connected to separate power supplies through the same resistances $R 3$ and $R 6$ (Fig. 3). When the $S 1$ and $S 2$ switches are switched, they are switched on charge or discharge.

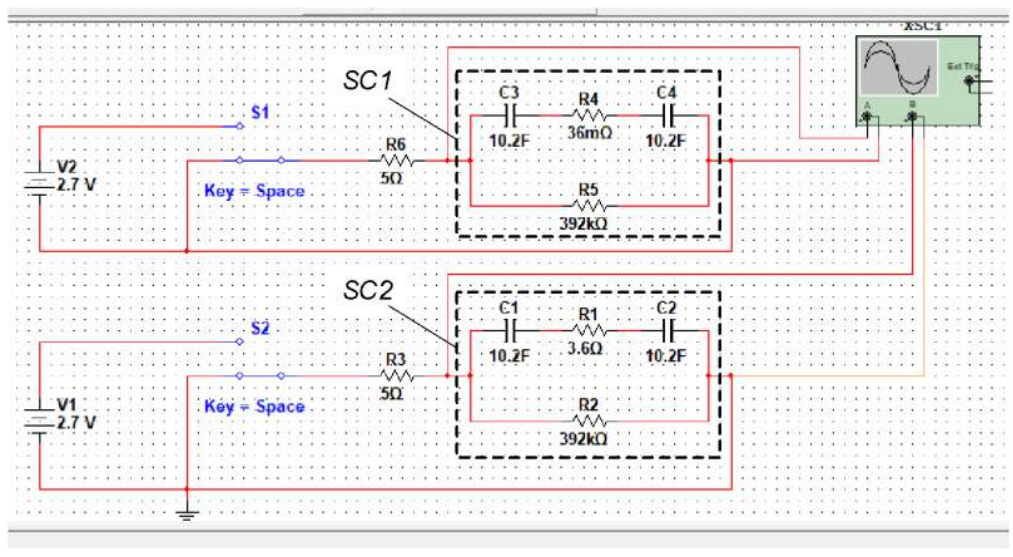

Fig. 3. Scheme for measuring the charging and discharging characteristics of two SCs with different values of internal resistances (screenshot of the NI Multisim environment)

The charging and discharging characteristics of SCs are compared using virtual oscilloscope tools and it is concluded that there are differences, in particular, between the values of voltage drop $\Delta U 1$ and $\Delta U 2$ when switching to discharge, which increases with internal resistance increase (Atamas, Chernetskyi \& Shapovalov, 2017). Note that for this study, synchronous switching of keys is not essential, however, if necessary, the keys can be replaced by a circuit built using relays, which are also available in the Multisim 11.0 library.

Note that in the absence of a real device in the training laboratory, its equivalent circuit can be built without prior experimental research on the passport data of various SCs as an industrial product ${ }^{8}$, available in free access online. Further modeling and research in the simulation environment allows us to investigate changes in the appearance of charging and discharging curves depending on the internal resistance and load resistance. In the same way you can compare the charging and discharging characteristics of the SC of different manufacturers.

Another method is based on the process of laboratory research of a real serial SC (Fig. 1) using laboratory equipment, digital measuring system and software. This version of the study of the properties of a SC is demonstrated by us in the research paper "Research of the SC and construction of its equivalent circuit", which can be found in the section "Research projects"

\footnotetext{
${ }^{7}$ This procedure can be performed according to the method of the laboratory project "Investigation of the capacitor" (stemua.science, 2018) ${ }^{8} \mathrm{https}: / /$ media.digikey.com/pdf/Data\%20Sheets/Nesscap\%20URL\%20links/ESHSR-0005C0-002R7.pdf
} 
(MANLab, 2018). In this experiment the $U=f(t)$ and $I=f(t)$ plots are obtained in the software environment of the digital measuring complex, basing on which the parameters of the equivalent circuit are then determined, which is built in the $\mathrm{NI}$ Multisim 11.0 environment, and then the charging (discharging) characteristics are measured, compared and conclusions are made about their identity. This proves the reliability of the created model and creates conditions for further virtual research, that concerns changing internal resistances, load resistance, supply voltage and so on. In addition, after measuring the charging and discharging characteristics and weighing the serial product, it is possible to determine such important parameters of the SC as the specific energy consumption, as well as the maximum and specific power.

Didactically promising from the point of view of the organization of training on the basis of STEM-approach is a technique of manufacturing and researching a printed 3D model of the SC which is usually applied by scientists for research of characteristics of the newest electrode materials and electrolytes [Chang et al, 2017]. This model consists of a permanent (fixed) part - a plastic body and two current terminals made of conductive material, which can be graphite or chemically inert metals. Electrodes made of highly porous conductive material and a separator impregnated with electrolyte, which can be replaced, are installed in the model cell (Fig. 4).

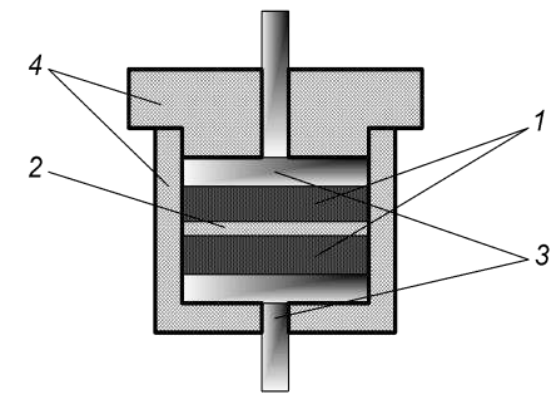

Fig. 4. Laboratory cell for the manufacture and study of SC:

1 - electrode material; 2 - separator; 3 - current leads; 4 - housing

Making a model of a SC at an educational institution is now available due to the rapid development and spread of technology and 3D printing, which can become part of the STEM project. Note that the body of the SC cell is made on the basis of non-conductive, and current leads - from electrically conductive grades of ABC-plastics. Activated carbon tablets or pieces of sorbent carbon tissue available in pharmacies can be used as electrode materials. Electrolytes for this model can be implemented as solutions of potassium hydroxide or sodium, sulfuric acid (battery electrolyte), and solutions of common salt and soda. The separator of such SC can be made of ordinary or filter paper.

In this method, in addition to the above study of charging and discharging characteristics, one can determine the specific capacity of carbon material, by weighing it before assembling the cell, and investigating the dependence of specific capacity and internal resistance of the SC on the composition and concentration of electrolyte. The next step in such an educational study may be to build in the NI Multisim 11.0 environment an equivalent substitution scheme based on experimental data and to conduct additional studies on the basis of the properties of the created SC.

The suggested methods of researching the properties of SC were tested in the activities of summer technical schools of

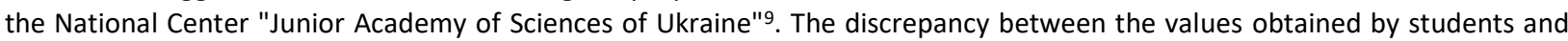
those obtained at the design stage of the laboratory project did not exceed $10 \%$, which is quite justified for school educational research.

\section{CONCLUSIONS}

The study showed that the teaching methods based on creation of equivalent circuits in simulation environments create a special niche in the issue of teaching electronics, electrical engineering and other STEM disciplines. This approach allows one to explore the properties and related processes in a real, serial device. Moreover, equivalent substitution schemes for SC can be obtained both on the basis of previous experimental studies and passport data of the product from open sources, which creates didactic conditions for various teaching methods: from an algorithmic laboratory project to an independent educational research. In addition, the NI Multisim software environment can be used remotely, for example, through one of the versions installed in the STEM-laboratory MANLab. Remote access is carried out using the Team Viewer program according to the schedule of a laboratory project using the specified tools (stemua.science, 2018). For the suggested methods, given the development of mobile learning technologies, in addition to NI Multisim, for example, the free and adapted to smartphones software product EveryCircuit ${ }^{10}$ can be used also.

In the future, it is planned to develop and test research methods based on 3D printing, which consist of didactically interconnected parts: design and manufacture of a set of laboratory cells with subsequent design and research of SC. The pedagogical aspects of STEM-oriented teaching of the basics of electronics need a separate thorough research.

\section{References}

1. Atamas, A. I., Chernetskyi, I. S., \& Shapovalov, V. B. (2017). Electricity and the basics of electronics. Laboratory Workshop: Workbook. Kyiv, Ukraine: MAN Publishing House. Retrieved from stemua.science

\footnotetext{
${ }^{9}$ http://man.gov.ua/ua/news/academy_news/fizika--dlya--obdarovanikh-br-nts--manu--proviv-litnyu-fizichnu-shkolu-za-napryamom-elektrika-/

${ }^{10}$ http://everycircuit.com/
} 
2. Chang, Y., Han, G., Xiao, Y., Chang, Y., Song, H., Li, M., Zhang, Y. (2017). Internal tandem flexible and compressible electrochemical capacitor based on polypyrrole/carbon fibers. Electrochimica Acta, 257, 335-344. doi:10.1016/j.electacta.2017.10.106

3. Chin, W. C., \& Zhuang, X. (2020). Reservoir Simulation and Well Interference. doi:10.1002/9781119283553.ch10

4. Conway, B. E. (2009). Electrochemical supercapacitors: scientific fundamentals and technological applications. New York: Kluwer Acad.

5. Djalal, M. R., \&Hr, H. (2019). Characteristic Test Of Transistor Based Multisim Software. PROtek : Jurnal Ilmiah Teknik Elektro, 6(2), 63-68. doi: 10.33387/protk.v6i2.1214

6. Grygorchak, I., Borysiuk, A., Shvets, R., Matulka, D., \& Hryhorchak, O. (2018). Supramolecular Design of Carbons for Energy Storage with the Reactanse-Sensor Functional Hybridity. East European Journal of Physics, (4), 48-57. doi: 10.26565/23124334-2018-4-06

7. Inamuddin, Boddula, R., Ahmer, M. F., \&Asiri, A. M. (2020). Morphology Design Paradigms for Supercapacitors. Milton: CRC Press LLC. doi: 10.1201/9780429263347

8. Johnson, D. (2014). Fundamentals of Electrical Engineering 1 I. Retrieved from http://legacy.cnx.org/content/col10040/1.9/

9. Kebede, M. A., \& Ezema, F. I. (2020). Electrochemical devices for energy storage applications. Boca Raton: CRC Press. doi: $10.1201 / 9780367855116$

10. Lyubomirov, S., Shehova, D., Asenov, S., \& Raydovska, V. (2019). Engineering Education And Examination Of Electronic Circuits Using Multisim. ICERI2019 Proceedings.doi: 10.21125/iceri.2019.1680

11. MANLab. (n.d.). Retrieved April 29, 2020, from https://stemua.science/

12. Noga, K. M., \& Palczynska, B. (2018). The Simulation Laboratory Platform Based on Multisim for Electronic Engineering Education. 2018 International Conference on Signals and Electronic Systems (ICSES), 269-274. doi: 10.1109/icses.2018.8507313

13. Ptak, P. (2018). Application Of Multisim And LTspice Software Packages To Simulate The Operation Of Electronic Components As An Alternative To Measurements Of Real Elements. Society.Integration.Education.Proceedings of the International Scientific Conference, 5, 409.doi: 10.17770/sie2018vol1.3120

14. Srikanth, M., Kumar, S., Gireesh, N., Manideep, T., Harichandana, B., \& Sangeetha, K. (2019).A Different way of Level measurement for PBL in Education of Students using NI-LabVIEW, Multisim and MyRIO. 2019 Innovations in Power and Advanced Computing Technologies (i-PACT).doi: 10.1109/i-pact44901.2019.8960023

15. Yadav, E. S., Rajesh, B., Srinivasan, C. R., \&Kalyan, P. S. (2019). A Study on Non-Linear Behavior of Memristor Emulator Using Multisim .Indonesian Journal of Electrical Engineering and Computer Science, 16 No. 3, 1213-1220. doi: 10.11591/ijeecs.v16.i3.pp.1213-1220

16. Yu, A., Chabot, V., \& Zhang, J. (2017). Electrochemical supercapacitors for energy storage and delivery: fundamentals and applications. Boca Raton: CRC Press, Taylor \& Francis Group. doi: 10.1201/b14671

\section{СУПЕРКОНДЕНСАТОР ЯК ДИДАКТИЧНИЙ ЗАСІБ НАВЧАННЯ УЧНІВ ОСНОВАМ ЕЛЕКТРОНІКИ У СЕРЕДОВИЩІ NI MULTISIM} A.I. Aтамась

Національний центр «Мала академія наук України», Україна

I.A. Сліпухіна

Національний авіаційний університет, Україно

I.С. Чернецький

Національний центр «Мала академія наук України», Україна

Ю.С. Шиховцев

Анотація.

Національний центр «Мала академія наук України», Україна

Формулювання проблеми. Навчальні дослідження технологічно актуальних і перспективних моделей девайсів з використанням середовищ симуляції, виокремили особливу дидактичну нішу. Затребуваність NI Multisim як пропедевтичного засобу формування інженерних навичок потребує дослідження організаційних і методичних засад його інтеграції у сучасне освітнє середовище.

Матеріали і методи. Застосовано теоретичні (порівняльний аналіз наукових даних, моделювання методичної системи навчання з використанням середовищ симуляції та інші), емпіричні (переважно обсерваційні) методи, а також комп'ютерне моделювання досліджуваних девайсів. Попередня дидактична апробація здійснювалася у рамках проєкту «Літні фрізикотехнічні школи» Національного центру «Мала академія наук України».

Результати. Особливості суперконденсатора як засобу навчання основам електроніки з використанням STEM підходу систематизовано у вигляді структурно-функціональної схеми. Навчальна методика грунтується на застосуванні equivalent circuit. Віртуальне дослідження серійних суперконденсаторів складається з розрахунку параметрів і побудови еквівалентної схеми у середовищі NI Multisim, аналізу зарядних (розрядних) характеристик та їх залежності від зовнішніх (внутрішніх) чинників. У натурному експерименті додатково визначають питому енергоємність суперконденсатора. Методика з використанням друкованого макету суперконденсатора доповнює експеримент можливостями визначення питомої ємності вуглецевого матеріалу, впливу концентрації застосованого електроліту на характеристики девайсу. 3D принтинг може бути частиною навчального STEM-проєкту.

Висновки. Методики на основі створення еquivalent circuits у середовищах симуляції дозволяють проєктувати навчальні дослідження властивостей і супутніх процесів у реальному, серійному девайсі, так і виготовленому у лабораторних умовах. Можливість використання паспортних даних серійних виробів створює дидактичні можливості для переходу від алгоритмізованої лабораторної роботи до самостійного навчального дослідження, зокрема, дистанційного або товіlе learning. Потребують подальшого дослідження відповідні методики на основі 3D принтингу, а також педагогічні аспекти STEM орієнтованого навчання основ електроніки.

Ключові слова: суперконденсатор, основи електроніки, еквівалентні схеми заміщення, NI Multisim, STEM, STEM-лабораторія МАНЛаб, 3D друк. 